\title{
56. ANISOTROPY IN COMPRESSIONAL-WAVE VELOCITIES AND WET-BULK DENSITIES OF CALCAREOUS SEDIMENTARY ROCKS, DEEP SEA DRILLING PROJECT LEG 62 ${ }^{1}$
}

\author{
Naoyuki Fujii, Department of Earth Sciences, Kobe University, Nada, Kobe 657, Japan
}

\section{INTRODUCTION}

Anisotropy in compressional-wave velocities in sedimentary rocks recovered by DSDP has been recognized by several investigators (Boyce, 1976; Tucholke et al., 1976; Carlson and Christensen, 1977). The anisotropy is also observed at elevated pressures in laboratory experiments, and thus probably persists at depth in some calcareous rocks (Schreiber et al., 1972; Christensen et al., 1973; Carlson and Christensen, 1979). Carlson and Christensen (1979) suggested that the observed velocity anisotropy was produced not by the alignment of cracks but by the alignment of $c$ axes of calcite perpendicular to bedding during compaction, diagenesis, and recrystallization.

On DSDP Leg 62, calcareous rocks were recovered from the western Mid-Pacific Mountains (sub-bottom depths of 452-823 m, Site 463) and southern Hess Rise (276-412 m, Site 465). Most of the calcareous rocks are horizontally laminated and color-banded, and ages are early Cenomanian to late Barremian (Site 463 and 465 reports, this volume).

The purpose of this study is to confirm the velocity anisotropy in the calcareous rocks and to identify any relationship of anistropy to bulk density, mean velocity, and burial depth.

\section{PROCEDURES}

All the samples treated here were minicored from calcareous rocks recovered at Sites 463 and 465 . The minicore samples, about $2.5 \mathrm{~cm}$ in diameter and 2 to $3 \mathrm{~cm}$ long, were carefully kept wet and ground flat to make at least two pairs of parallel sides, including one normal to the core axis. Measurements of wet-bulk density by 2 -minute GRAPE (gamma-ray attentuation porosity evaluator) and compressional-wave velocity by Hamilton Frame Velocimeter (Boyce, 1976) were made on the same minicore samples. Gravimetric wet-bulk density was also measured for a small chip cut from the minicore sample or adjacent portion of the core.

The precision of wet-bulk densities are within $2 \%$ for both 2-minute GRAPE and gravimetric methods. The wet-bulk densities obtained by the 2-minute GRAPE method tend to be slightly larger (by about $2 \%$ on the average) than those obtained by the gravimetric method, as indicated in Table 1. Because measurements of density by the two methods were made on different parts of the specimen, sample heterogeneity could account for this discrepancy. Although systematic differences in correction methods for density evaluations by the two methods remain possible, I take the average value of wet-bulk densities by the two methods in later discussions.

The precision of measurements was normally within $1 \%$ and always less than $3 \%$ in repeated measurements of compressional-wave velocity for the samples listed in Table 1.

\footnotetext{
${ }^{1}$ Initial Reports of the Deep Sea Drilling Project, Volume 62.
}

\section{RESULTS AND INTERPRETATIONS}

Measurements of compressional-wave velocity and anisotropy and density are presented in Table 1 .

Figure 1 shows the relation between wet-bulk density and compressional-wave velocity of calcareous rocks from Sites 463 and 465 , together with the averaged curve for oceanic sediments and rocks given by Nafe and Drake (1963). The sediment layer in the uppermost oceanic crust is likely to be saturated with sea water, and the pore pressure varies between hydrostatic and lithostatic pressure (Brace, 1971). Under in situ conditions for the samples studied at Sites 463 and 465 , the effective pressure (confining pressure minus pore pressure) should be less than 100 bars. Then the compressionalwave velocities obtained at atmospheric pressure in a water-saturated condition should not be much different from those of in situ conditions, at least for lowporosity calcareous rocks, such as firm limestones.

In their gross trend, the values obtained in this study seem to fit the Nafe-Drake curve. However, the velocity values for the vertical direction in the range of 2.5 to 4 $\mathrm{km} / \mathrm{s}$ are lower by 10 to $20 \%$ than the value of the Nafe-Drake curve at the same density. The difference in compressional-wave velocity between the horizontal and vertical directions is clearly shown in Figure 2, for the samples listed in Table 1 (except chert). The difference is important in determining the velocity structure in the uppermost regions of the oceanic crust by the commonly used variable-angle reflection method, as noted by Carlson and Christensen (1979).

Anisotropy $(A)$ is defined as (Carlson and Christensen, 1977)

$$
A=2\left(V_{\mathrm{h}}-V_{\mathrm{v}}\right) /\left(V_{\mathrm{h}}+V_{\mathrm{v}}\right)
$$

where $V_{\mathrm{h}}$ and $V_{\mathrm{v}}$ are the measured compressional-wave velocities in the propagating directions perpendicular and parallel to the core axis, respectively. When velocities of compressional waves were measured in mutually perpendicular horizontal directions, the arithmetic mean was assigned to $V_{\mathrm{h}}$. The frequency distribution of anisotropy for the values obtained is shown in Figure 3. The mean anisotropy is $5.2 \%$.

Carlson and Christensen $(1977,1979)$ showed increase in anisotropy with increases in mean velocity, bulk density, and depth of burial for semi-indurated calcareous sediments from the western South Atlantic (Sites 354, 356, and 357). Figure 4 shows wet-bulk density versus velocity anisotropy for calcareous rocks from 
Table 1. Compressional-wave velocities and anisotropies and wet-bulk densities of calcareous rocks and some cherts from Sites 463 and 465 .

\begin{tabular}{|c|c|c|c|c|c|c|c|}
\hline \multirow[b]{2}{*}{$\begin{array}{c}\text { Sample } \\
\text { (interval in cm) }\end{array}$} & \multicolumn{3}{|c|}{$\begin{array}{l}\text { Velocity } \\
(\mathrm{km} / \mathrm{s})\end{array}$} & \multirow[b]{2}{*}{$\begin{array}{c}\text { Anisotropy } \\
(\%)\end{array}$} & & $\begin{array}{l}\text { nsity } \\
\mathrm{cm}^{3} \text { ) }\end{array}$ & \\
\hline & $V_{\mathrm{v}}$ & $V_{\mathrm{hl}}$ & $V_{\mathrm{h} 2}$ & & $\begin{array}{l}\text { 2-Min. } \\
\text { GRAPE }\end{array}$ & Gravimetric & Remarks \\
\hline $463-26-1,58-61$ & 1.69 & 1.69 & - & 0 & 1.85 & - & Foraminifer-nannofossil chalk \\
\hline $26-5,46-48$ & 1.71 & 1.74 & - & 1.74 & - & 1.76 & Foraminifer-nannofossil chalk (minicore) \\
\hline $26-5,50-52$ & 1.72 & 1.73 & - & 0.58 & - & - & Foraminifer-nannofossil chalk (split core) \\
\hline $27-1,140-142$ & 1.91 & 1.78 & - & -7.04 & - & 1.78 & Foraminifer-nannofossil chalk \\
\hline $29-1,34-36$ & 1.79 & 1.81 & - & 1.11 & 1.84 & - & Foraminifer-nannofossil chalk \\
\hline $30-2,87-89$ & 2.14 & 2.21 & - & 3.22 & - & 1.97 & Foraminifer-nannofossil chalk \\
\hline $30, \mathrm{CC}$ & 2.51 & 2.60 & - & 3.52 & - & 1.99 & Limestone (white) \\
\hline $33-1,137-139$ & 2.06 & 2.17 & - & 5.20 & 2.00 & - & Foraminifer-nannofossil chalk \\
\hline $34-1,70-72$ & 1.91 & 2.00 & - & 4.60 & 1.81 & - & Foraminifer-nannofossil chalk \\
\hline $34-2,142-144$ & 2.10 & 2.02 & - & -3.88 & 1.90 & - & Foraminifer-nannofossil chalk \\
\hline $53-1,121-123$ & 2.365 & 2.32 & 2.37 & -0.85 & 2.15 & 2.11 & Limestone (green) \\
\hline $53, \mathrm{CC}$ & 5.77 & 5.59 & - & - & 2.64 & 2.60 & Chert (pale-brown) \\
\hline $54, \mathrm{CC}$ & 2.54 & 2.55 & 2.53 & 0 & 2.11 & 2.08 & Limestone (white) \\
\hline $54, \mathrm{CC}$ & 5.52 & 5.61 & - & - & 2.60 & 2.59 & Chert (pale-brown) \\
\hline $55-1,19-21$ & 2.40 & 2.42 & 2.43 & 1.04 & 2.17 & 2.16 & Limestone (green) \\
\hline $55-1,79-81$ & 4.93 & 5.37 & - & - & 2.45 & 2.50 & Chert (gray) \\
\hline $57-1,86-88$ & 3.56 & 3.70 & 3.73 & 4.26 & 2.48 & 2.41 & Limestone (brown) \\
\hline $57-2,2-4$ & 2.53 & 2.56 & 2.60 & 1.96 & 2.14 & 2.14 & Limestone (gray) \\
\hline $58-1,40-42$ & 3.66 & 3.77 & 3.81 & 3.49 & 2.45 & 2.40 & Limestone (pale-brown) \\
\hline $58-2,53-55$ & 3.41 & 3.44 & 3.59 & 3.03 & 2.39 & 2.35 & Limestone (light-gray) \\
\hline $58-3,29-31$ & 3.09 & 3.42 & 3.44 & 10.43 & 2.39 & 2.39 & Limestone (green and pale-brown) \\
\hline $58, \mathrm{CC}$ & 3.77 & 3.97 & 3.95 & 4.92 & 2.51 & 2.51 & Limestone (pale-brown) \\
\hline $59-1,65-68$ & 3.62 & 3.75 & - & 3.53 & 2.41 & 2.39 & Limestone (white) \\
\hline $59-3,89-91$ & 3.08 & 3.33 & - & 7.80 & 2.36 & 2.39 & Limestone (pale-brown) \\
\hline $60-2,61-63$ & 3.25 & 3.40 & - & 4.51 & 2.32 & 2.30 & Limestone (pale-brown) \\
\hline $60-4,67-69$ & 2.91 & 3.19 & - & 9.18 & 2.38 & 2.36 & Limestone (dark-brown) \\
\hline $61-1,48-50$ & 4.07 & 4.45 & - & 8.92 & 2.53 & 2.45 & Limestone (brown) \\
\hline $62-1,15-17$ & 2.64 & 2.85 & - & 7.65 & 2.33 & 2.26 & Limestone (gray; coarse-grained) \\
\hline $62-3,95-97$ & 3.23 & 3.48 & - & 7.45 & 2.39 & 2.32 & Limestone (pale-brown) \\
\hline $63-1,9-11$ & 3.37 & 3.61 & 3.51 & 5.48 & 2.35 & 2.30 & Limestone (pale-brown and pink) \\
\hline $63-2,117-119$ & 3.28 & 3.51 & 3.42 & 5.49 & 2.34 & 2.27 & Limestone (white) \\
\hline $64-1,35-37$ & 2.98 & 3.23 & 3.25 & 8.36 & 2.26 & 2.20 & Limestone (white) \\
\hline $64-2,110-112$ & 3.31 & 3.44 & 3.42 & 3.56 & 2.40 & 2.35 & Limestone (brown) \\
\hline $65-1,64-66$ & 3.23 & 3.44 & 3.39 & 5.57 & 2.31 & 2.31 & Limestone (pale-brown and pink) \\
\hline $65-2,40-42$ & 3.46 & 3.81 & 3.69 & 8.04 & 2.40 & 2.34 & Limestone (pale-brown) \\
\hline $66-1,57-59$ & 3.06 & 3.35 & 3.30 & 8.30 & 2.32 & 2.26 & Limestone (white-gray) \\
\hline $66-2,20-21$ & 3.04 & 3.44 & 3.21 & 8.96 & 2.32 & 2.22 & Limestone (gray) \\
\hline $67-1,69-71$ & 3.24 & 3.49 & 3.47 & 7.14 & 2.43 & 2.34 & Limestone (gray) \\
\hline $67-2,21-23$ & 3.12 & 3.33 & 3.36 & 6.96 & 2.34 & 2.26 & Limestone (gray) \\
\hline $69-2,25-27$ & 2.45 & 2.62 & - & 6.71 & 2.14 & 2.16 & Limestone (gray-green) \\
\hline $69-2,98-100$ & 2.27 & 2.43 & - & 6.81 & 2.20 & 2.21 & Limestone (gray-green) \\
\hline $70-1,59-61$ & 3.42 & 3.58 & - & 4.57 & 2.19 & 2.19 & Limestone (gray, black inclusion) \\
\hline $70-4,66-68$ & 2.53 & 3.00 & - & 17.0 & 2.23 & 2.14 & Limestone (gray) \\
\hline $70-5,113-115$ & 2.67 & 2.68 & - & 0.37 & & 1.98 & Limestone (black) \\
\hline $71-1,21-23$ & 2.24 & 2.45 & - & 8.96 & 1.95 & 1.90 & Limestone (green) \\
\hline $71-2,121-123$ & 2.93 & 3.38 & 3.36 & 13.97 & 2.34 & 2.26 & Limestone (white; coarse-grained) \\
\hline $72-2,102-104$ & 2.98 & 3.12 & - & 4.59 & 2.09 & 1.62 & Limestone (gray) \\
\hline $72-3,30-32$ & 2.92 & 3.06 & - & 4.68 & 2.09 & 2.10 & Limestone (gray) \\
\hline $73-1,8-10$ & 3.56 & 3.78 & - & 5.99 & 2.40 & 2.35 & Limestone (light-gray) \\
\hline $73-2,103-105$ & 3.01 & 3.18 & - & 5.49 & 2.11 & 2.09 & Limestone (gray) \\
\hline $74-1,76-78$ & 2.56 & 2.76 & - & 7.52 & 1.99 & 2.00 & Limestone (green) \\
\hline $76-1,41-43$ & 3.40 & 3.55 & - & 4.32 & 2.34 & 2.25 & Limestone (white, black inclusion) \\
\hline $76-1,123-125$ & 2.33 & 2.30 & - & -1.30 & 2.09 & 1.99 & Limestone (gray) \\
\hline $77-1,30-32$ & 3.16 & 3.29 & - & 4.03 & 2.35 & 2.28 & Limestone (white, black stripes) \\
\hline $78-1,44-46$ & 3.55 & 3.58 & - & 0.84 & 2.34 & 2.31 & Limestone (white, black stripes) \\
\hline $79-1,42-44$ & 4.61 & 4.63 & - & 0.43 & 2.58 & 2.49 & Limestone (white) \\
\hline $80-1,36-38$ & 3.93 & 4.17 & - & 5.93 & 2.57 & 2.54 & Limestone (pebbly, coral reef sed.) \\
\hline $81-1,76-78$ & 3.97 & 4.05 & - & 2.00 & 2.65 & 2.55 & Limestone (pebbly) \\
\hline $82-1,31-33$ & 3.12 & 3.43 & - & 9.46 & 2.36 & 2.29 & Limestone (gray) \\
\hline $83-1,66-68$ & 2.75 & 2.74 & - & -0.36 & 2.20 & 2.16 & Limestone (white) \\
\hline $83-2,30-32$ & 3.80 & 4.19 & - & 9.76 & 2.43 & 2.53 & Limestone (white and gray stripes) \\
\hline $84-1,28-30$ & 4.02 & 4.20 & - & 4.38 & 2.48 & 2.60 & Limestone (pebbly) \\
\hline $84-1,114-116$ & 3.46 & 3.67 & - & 5.89 & 2.38 & 2.49 & Limestone (light-gray) \\
\hline $85-1,43-45$ & 3.24 & 3.68 & - & 12.7 & 2.26 & 2.37 & Limestone (gray) \\
\hline $85-2,62-64$ & 4.29 & 4.59 & - & 6.76 & 2.57 & 2.48 & Limestone (pebbly) \\
\hline $86-1,6-8$ & 4.53 & 4.87 & - & 7.23 & 2.58 & 2.48 & Limestone (white) \\
\hline $88-1,82-84$ & 3.93 & 4.20 & - & 6.64 & 2.56 & 2.45 & Limestone (pebbly) \\
\hline $89-1,38-40$ & 3.52 & 3.58 & - & 1.69 & 2.45 & 2.39 & Limestone (gray) \\
\hline $89-1,96-98$ & 3.78 & 3.92 & - & 3.64 & 2.46 & 2.12 & Limestone (gray; coarse-grained) \\
\hline $465 \mathrm{~A}-26-1,68-70$ & 4.40 & 4.48 & - & 1.80 & 2.52 & 2.48 & Limestone (olive-gray) \\
\hline $27-2,11-13$ & 4.32 & 4.60 & - & 6.28 & 2.57 & 2.44 & Limestone (olive-gray) \\
\hline $28-2,64-66$ & 3.82 & 3.95 & - & 3.35 & 2.54 & 2.46 & Limestone (gray, hard) \\
\hline $29-1,33-35$ & 3.73 & 3.77 & - & 1.07 & 2.48 & 2.43 & Limestone (gray) \\
\hline $32-1,74-76$ & 3.05 & 3.28 & - & 7.27 & 2.31 & 2.37 & Limestone (olive-gray) \\
\hline $33-2,140-142$ & 2.03 & 2.15 & - & 5.74 & 2.04 & 1.99 & Limestone (olive-gray, soft) \\
\hline $34-1,1-3$ & 2.64 & 3.27 & - & 21.32 & 2.32 & 2.31 & Limestone (olive-gray, soft) \\
\hline $35-1,5-7$ & 3.57 & 3.96 & - & 10.36 & 2.49 & 2.43 & Limestone (olive-gray) \\
\hline $36-1,132-134$ & 2.11 & 2.15 & - & 1.88 & 1.96 & 1.97 & Limestone (olive-gray, cracks) \\
\hline $37-1,52-54$ & 1.88 & 1.99 & - & 5.68 & 1.94 & 1.88 & Limestone (olive-gray, cracks) \\
\hline $38-1,105-107$ & 2.09 & 2.20 & - & 5.13 & 1.88 & 1.87 & Limestone (olive-gray) \\
\hline $39-2,45-47$ & 3.85 & 4.29 & - & 10.81 & 2.53 & 2.45 & Limestone (light-olive-gray) \\
\hline $40-1,83-85$ & 3.59 & 4.06 & - & 12.29 & 2.54 & 2.43 & Limestone (olive-gray) \\
\hline
\end{tabular}

Note: $V_{\mathrm{y}}$ is the direction of compressional-wave propagation parallel to the core axis, (i.e., vertical) $V_{\mathrm{h} 1}$ and $V_{\mathrm{h}} 2$ are the directions of compressional-wave propagation mutually perpendicular and normal to the core axis. Anisotropy is defined as $2\left(V_{\mathrm{h}}-V_{\mathrm{v}}\right) /$ $\left(V_{\mathrm{h}}+V_{\mathrm{y}}\right)$, where $V_{\mathrm{h}}$ and $V_{\mathrm{y}}$ are the directions of compressional-wave propagation normal to and parallel to the core axis, respectively; when $V_{\mathrm{h} 1}$ and $V_{\mathrm{h} 2}$ are measured, $V_{\mathrm{h}}=\left(V_{\mathrm{h} 1}+V_{\mathrm{h} 2}\right) / 2$. 


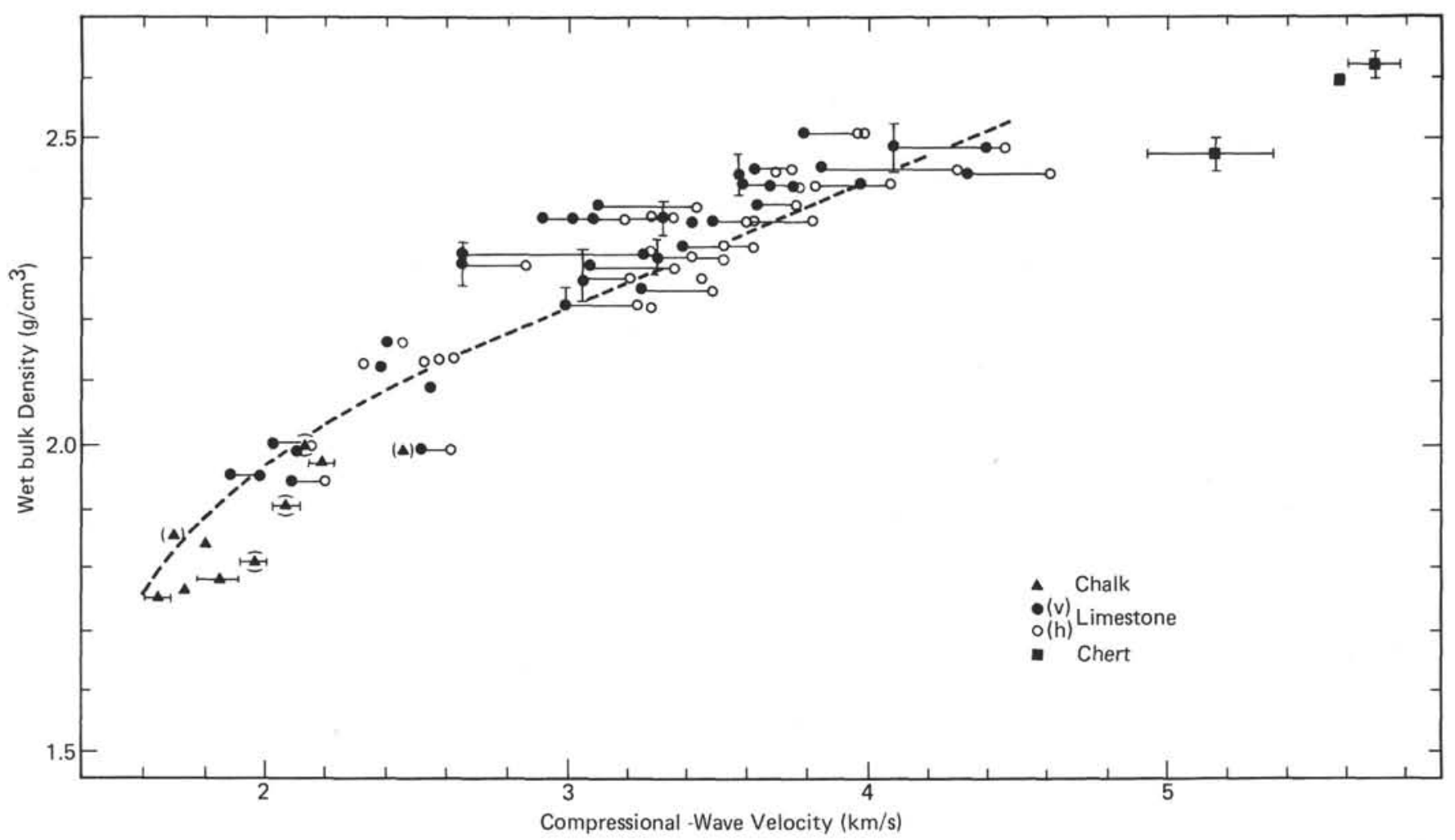

Figure 1. Wet-bulk density versus compressional-wave velocity of calcareous rocks and some cherts from Sites 463 and 465 . Open and solid circles respectively indicate the directions of velocity normal to and parallel to the core axis, (i.e., horizontal vertical directions). Symbols in parentheses are less-accurate values. Bars show precision. Dashed curve is from Nafe and Drake (1963).

Sites 463 and 465 . No such dependence of anisotropy on bulk density is found. Because the velocity values plotted against depth of burial scatter considerably (Site 463 and 465 reports, this volume), increases of mean velocity and bulk density with depth of burial are so unclear that no increase of anisotropy with depth of burial is expected on the basis of the data of this study.

\section{ACKNOWLEDGMENTS}

The opportunity to participate on DSDP Leg 62 is appreciated. I wish to thank $\mathrm{K}$. Ito and $\mathrm{Y}$. Kobayashi for critically reading the manuscript. I am indebted to J. Asakura and K. Fujimoto for their typing and drafting assistance. This work was partly supported by a grant from the Ministry of Education.

\section{REFERENCES}

Boyce, R. E., 1976. Definitions and laboratory techniques of compressional sound velocity parameters and wet-water content, wetbulk density, and porosity parameters by gravimetric and gamma ray attenuation technique. In Jackson, E. D., Schlanger, S. O., et al., Init. Repts. DSDP, 33: Washington (U.S. Govt. Printing Office), 931-958.

Brace, W. F., 1971. Resistivity of saturated crustal rocks to $40 \mathrm{~km}$ based on laboratory studies. In Hancock, J. G. (Ed.), The Struc- ture and Physical Properties of the Earth's Crust: Geophys. Monogr., 14, pp. 243-256.

Carlson, R. L., and Christensen, N. I., 1977. Velocity anisotropy and physical properties of deep-sea sediments from the western South Atlantic. In Supko, P. R., Perch-Nielsen, K., et al., Init. Repts. $D S D P$, 39: Washington (U.S. Govt. Printing Office), 555-559. , 1979. Velocity anisotropy in semi-indurated calcareous deep sea sediments. J. Geophys. Res., 84:205-211.

Christensen, N. I., Fountain, D. M., and Stewart, R. J., 1973. Ocean crustal basement: a comparison of seismic properties of DSDP basalts and consolidated sediments. Mar. Geol., 15:215.

Nafe, J. E., and Drake, C. L., 1963. Physical properties of marine sediments. In Hill, M. N. (Ed.) The Sea (Vol. 3): New York (Interscience), 794-815.

Schreiber, E., Fox, J., and Reterson, J., 1972. Compressional sound velocities in semi-indurated sediments and basalts from DSDP Leg 11. In Hollister, C. D., Ewing, J. I., et al., Init. Repts. DSDP, 11: Washington (U.S. Govt. Printing Office), 723.

Tucholke, B. E., Edgar, N. T., and Boyce, R. E., 1976. Physical properties of sediments and correlations with acoustic stratigraphy: Leg 35, Deep Sea Drilling Project. In Hollister, C. D., Craddock, C., et al., Init. Repts. DSDP, 35: Washington (U.S. Govt. Printing Office), 229-249. 


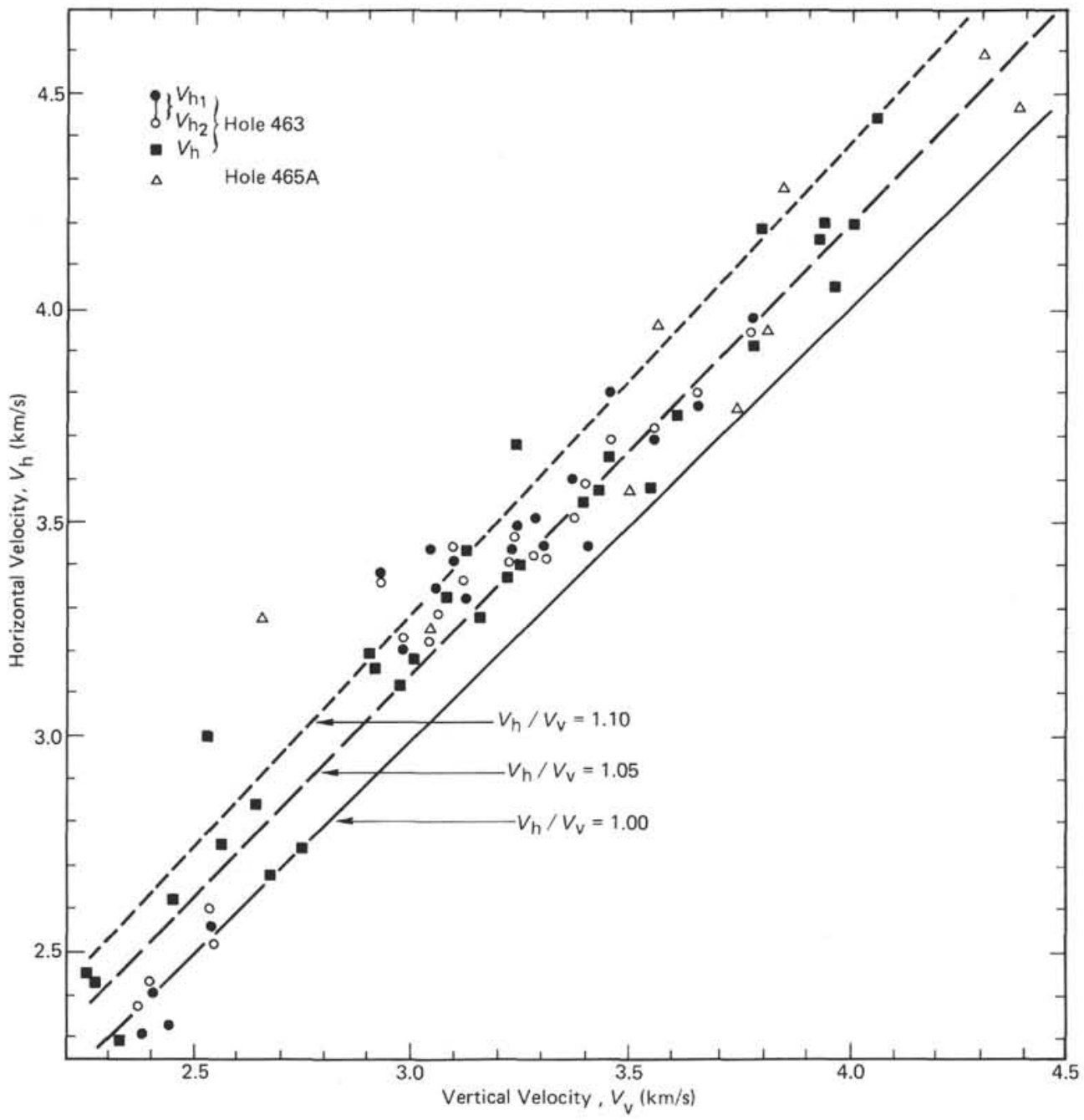

Figure 2. Velocity anisotropy of calcareous rocks from Sites 463 and 465 . Open and solid circles indicate the pair of two values for mutually perpendicular horizontal directions of compressional-wave propagation, from Hole 463. Solid squares represent Hole 463, one horizontal direction measured.

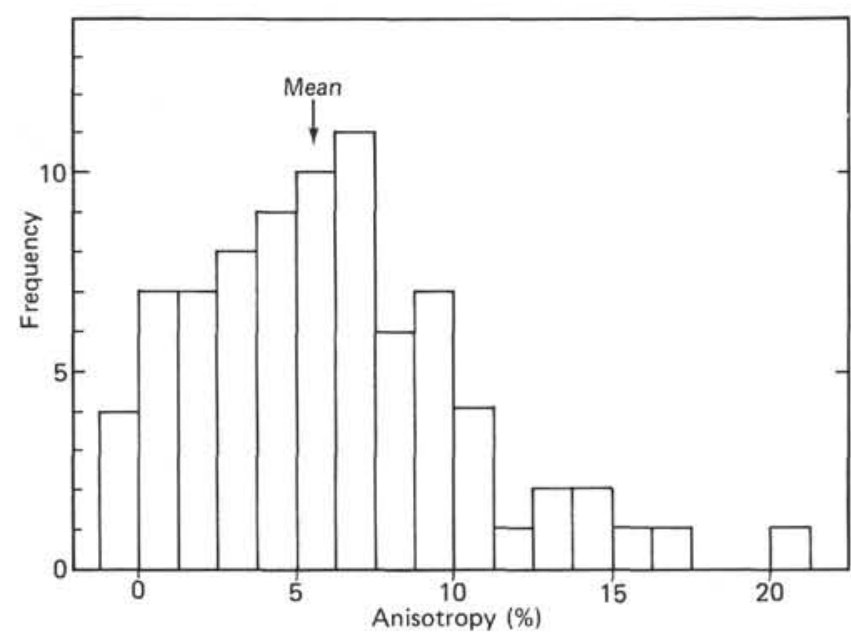

Figure 3. Frequency distribution of velocity anisotropy for the sample listed in Table 1 (except chert).

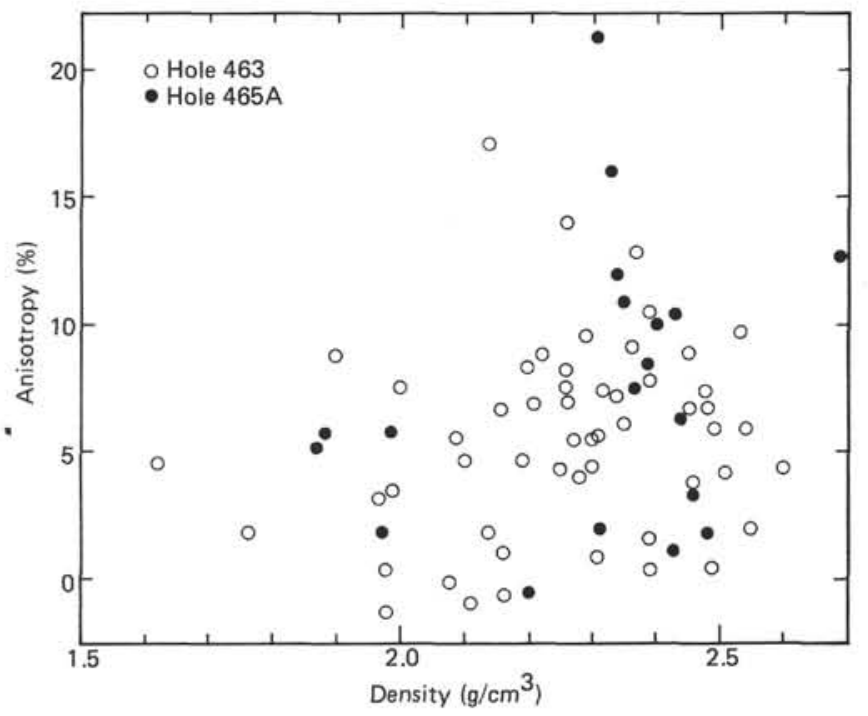

Figure 4. Wet-bulk density versus velocity anisotropy for the sample listed in Table 1 (except chert). 